\title{
Irrigation, Commercialization, and Social Change in Nineteenth-Century Inner Mongolia*
}

\author{
Y I WANG \\ Center for Chinese Studies, University of California, Berkeley \\ Berkeley, CA 94720-2328, USA
}

E-mail: yiwang $@$ berkeley.edu

\begin{abstract}
AвSTRAст: This article examines the rise of an irrigation economy in Hetao along the Yellow River during the nineteenth century, and uses it as a case study to illustrate how the periphery played a major and hitherto overlooked role in the development of the Chinese economy, which confounds the conventional view of a Chinese path of development that replicated smallholder farming. I focus on a group of Han entrepreneurs known as land merchants (dishang) who combined capital and expertise in irrigation development, and introduced a new set of property regime and socio-technical arrangements that fundamentally changed the frontier society. By linking the changes in local society to regional and global processes, this study demonstrates the centrality of the periphery as not only a zone of possibility and experimentation, but more importantly, a "contact zone" that facilitated China's integration into a new global market system.
\end{abstract}

The territorial and demographical expansion of the Qing Empire (I644-I9I I) during the eighteenth century ushered in an era of unprecedented movement of capital and population across the Great Wall. Long-distance trade, developed in the wake of Qing military campaigns against the Zunghars (I690-I696) and dominated by Shanxi merchants, drew heavy flows of Chinese goods into the grassland and produced a corresponding flow of livestock and pastoral products in the opposite direction. At the same time, population pressure in north China and increasing demand for grain on the steppe combined to push Han migrants from Zhili, Shanxi, and Shaanxi into the pastoral regions of the Mongols, producing a belt of agricultural settlements along the Great Wall. Mercantile expansion and labor migration converged in the nineteenth century to create an economic boom in the Han-Mongol frontier of Hetao along the

\footnotetext{
* The author is indebted to Professor Jacob Eyferth for his insights and invaluable comments on various versions of this article. I would also like to thank the anonymous reviewer for many helpful comments and suggestions.
} 
Yellow River. In contrast to previous migrations, that were typically strategically or ecologically driven and replicated traditional modes of smallholder farming, agricultural expansion in Hetao was planned, largescale, and showed features that are best described as capitalist.

The development of the late imperial Chinese economy has been the focus of heated scholarly debate. Chinese historians during the Maoist period identified the expansion of commodity production and wage labor from the sixteenth century onward as "sprouts of capitalism", comparable to changes in European economies. Jing Su and Luo Lun argued that the emergence of managerial landlords in Shandong indicated a qualitative change towards a proto-capitalist economy. ${ }^{\mathrm{I}}$ In contrast, Western scholarship since the I960s emphasized the stagnation and involution of China's rural economy, arguing that, despite considerable commercialization and urbanization, Chinese agriculture remained bound to a path of small peasant family farming that was incapable of transformative growth toward capitalism. ${ }^{2}$ Recent scholarship, however, has begun to challenge the conventional wisdom, by examining economic and social change in early modern China in relation to the political institutions and ecological conditions, and placing Chinese economic developments in the broader context of the interregional and global economies. ${ }^{3}$

This article addresses some of the crucial issues in this debate from the perspective of China's periphery. I argue that the periphery is no longer peripheral if we shift perception from the imperial capital to regional or global perspectives. Instead, it stands out as a zone of possibility and experimentation where tendencies that are latent elsewhere are developed, and a "contact zone" where China's integration into a new global economy is most visible. In this sense, the periphery plays a significant role in expanding and enriching our understanding of early modern China and its economic development.

In particular, I focus on a group of Han entrepreneurs known as land merchants (dishang) who combined commercial capital and technical

I. Xu Dixin and Wu Chengming, Zhongguo zibenzhuyi de mengya [Sprouts of Capitalism in China], I (Beijing, I985); Jing Su and Luo Lun, Landlord and Labor in Late Imperial China: Case Studies from Shandong, trans. Endymion Wilkinson (Cambridge, MA, I978).

2. Dwight Perkins, Agricultural Development in China, 1368-1968 (Chicago, IL, I969); Ramon Myers, The Chinese Peasant Economy: Agricultural Development in Hopei and Shantung, I 890-1949 (Cambridge, MA, 1970); Mark Elvin, The Pattern of the Chinese Past (Stanford, CA, 1973); Philip Huang, The Peasant Economy and Social Change in North China (Stanford, CA, I985); Kang Chao, Man and Land in Chinese History: An Economic Analysis (Stanford, CA, 1986); Philip Huang, The Peasant Family and Rural Development in the Yangzi Delta, 1350-1988 (Stanford, CA, I990).

3. Kenneth Pomeranz, The Great Divergence: Europe, China, and the Making of the Modern World Economy (Princeton, NJ, 2000); R. Bin Wong, China Transformed: Historical Change and the Limits of European Experience (Ithaca, NY, 1997); Li Bozhong, Agricultural Development in Jiangnan, I620-I 850 (New York, 1998). 
expertise in irrigation development. In a time span of three generations, they were able to develop a capital-intensive, market-oriented rural economy based on massive capital investment, wage labor, and commercialized agriculture. Although their endeavors were abruptly cut short by the state expropriation in I902, they not only created a prosperous agricultural economy outside the Great Wall, but also left behind a legacy that influenced policies of the late Qing, Republican, and PRC governments. Depending on the political climate and ideological paradigms of the time, there are controversial opinions among historians regarding these land merchants, varying from "semifeudal" and "parasitic" landlords to "bourgeois entrepreneurial farmers". ${ }^{4}$ In the following, I propose to offer a more nuanced assessment of land merchants as social actors in their social and historical context that ended up bringing transformative changes to the frontier as well as core parts of China.

\section{A CHANGING FRONTIER}

Before we investigate the set of changes introduced by Chinese commercial and agricultural expansion, it is helpful to provide an overview of the existing political and social structure in the Mongol periphery. Historically, what is now Inner Mongolia was a contact zone that alternated in control between various nomadic groups of the steppe and settled Chinese dynasties in the south which competed there for living space and political power. For mainstream Confucianism, the nomads constituted the cultural Other against which the Chinese civilization defined itself. The Great Wall, constructed in the wake of military tension between the Ming Dynasty (1368-1644) and invading Mongols, exemplified this physical and symbolic demarcation between "interior" (nei) and "exterior" (wai), "cultured" (bua) and "barbarian" (yi).s

Under the Manchu-ruled Qing dynasty, the borders were pushed outwards, far beyond the Great Wall. The Mongol lands became part of the Qing Empire, and the Mongols were given a privileged position as military allies and co-rulers of the empire. At the same time, Qing rulers transformed Mongolia by organizing the Mongols into a multitude of territorial-based subdivisions called banners (Mongolian: khoshuu,

4. For the negative view, see Anzai Kuraji, "Shinmatsu ni okeru suien no kaikon" [Land reclamation in Suiyuan in late Qing], part I, Mantetsu Chösa Geppō, I8:I 2 (1938), pp. I-43, 25; idem, "Shinmatsu ni okeru suien no kaikon" [Land reclamation in Suiyuan in late Qing], part 2, Mantetsu Chōsa Geppō, I9: (1939), pp. I4-62, I9-20; Imahori Seiji, Chügoku no shahai kōzö: anshan rejimu ni okeru 'kyödotai' [The social structure of China: "community" in the ancient régime] (Tokyo, 1953), pp. 4I-55. For the positive assessment, see Zhang Zhihua, "Lüelun hetao dishang" [A brief inquiry on land merchants of Hetao], in Liu Haiyuan (ed.), Neimenggu kenwu yanjiu [Studies on land reclamation of Inner Mongolia] (Hohhot, 1990), pp. $8 \mathrm{I}-99,97$.

5. Arthur Waldron, The Great Wall of China: From History to Myth (Cambridge, 1990). 
Chinese: $q$ i) which were ruled by hereditary princes. The banners were then grouped into leagues (Mongolian: chuulghan, Chinese: meng) under the supervision of the Lifanyuan (Court of Dependency Affairs) in Beijing, the central agency in charge of the Mongol dependencies and Tibet. The system was designed to curtail the military power of the Mongols by weakening their horizontal solidarity while strengthening their bonds with the Manchu emperor. ${ }^{6}$ The Qing court also patronized Tibetan Buddhism that was dominant among the Mongols, and separated Han and Mongols so as to protect the nomadic culture. A rigorous ban was in effect that prohibited Han Chinese from cultivating Mongol lands. It was only under special circumstances such as military campaigns or famine relief that the ban was temporarily lifted. The few Han cultivators who were allowed to till the land beyond the Great Wall were forbidden to bring families, marry Mongolian women, or construct permanent buildings, and were obliged to return to their native places after the harvest each year. ${ }^{7}$

A set of changes in the eighteenth century, however, fundamentally altered the power balance between Han and Mongols. First, the Qing military expansion across the Eurasian steppe doubled the size of the empire to include the peripheries of Outer Mongolia, Xinjiang, and Tibet. This greatly facilitated the commercial penetration of Han merchants who were given direct access to the steppe for the first time. These merchants, the majority of whom were from Shanxi province, played a central role in supplying the Qing troops during the military expeditions across the steppe and mediating the financial needs of the Manchu and Mongol ruling elites. The lucrative long-distance trade resulted in a string of flourishing frontier market centers and an extensive trading network across the steppe. By the end of the eighteenth century, even the remotest corners of Mongolia had been exposed to a monetized economy based on silver.

A second change was the doubling of the Han Chinese population over the course of the eighteenth century. Overpopulation and environmental degradation combined to push a steady flow of Han migrants from adjacent provinces such as Shanxi and Shaanxi into the grassland. This started as a voluntary exchange, with the Mongols providing land in return for an annual rent in kind. Over time, the Han advance brought about a growing commercialization and privatization of land, as the communally owned Mongol land gradually passed into private ownership. While the Mongols retained the right of rent collection, the actual land use was permanently transferred to Han migrants. Another change was the expansion of a centralized bureaucracy to areas outside the Great

6. For a more thorough introduction to the banner and league system, see Sechin Jagchid and Paul Hyer, Mongolia's Culture and Society (Boulder, CO, 1979), pp. 3i 8-335.

7. Qinding Lifanyuan zeli [Imperially Commissioned Collected Statutes of the Court of Dependency Affairs] (Tianjin, 1998), pp. 297-306. 


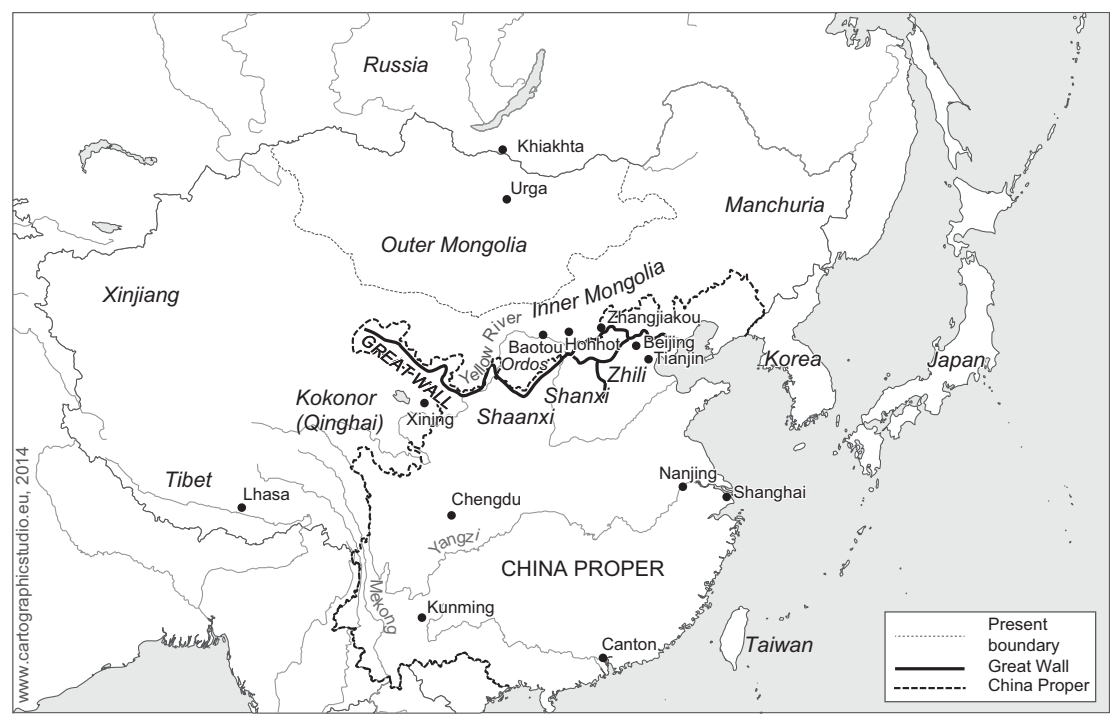

Figure I. The Qing Empire (c.1800).

Wall. By i 800 , a total of twenty centralized administrative units had been established in Inner Mongolia, to manage the growing Han population there. Thus the territorial and demographical expansion of the Qing created the legal and administrative framework for the influx of Chinese capital and migrants into the Mongol periphery.

At the microcosmic level, a set of unique natural and social conditions made Hetao a perfect locus of change. Geographically, Hetao (meaning "river loop", a.k.a. Houtao) is located between the old bed of the Yellow River and its present course, on the north-western section of the Ordos Plateau. The area was created by a shift of the river course during the eighteenth century, which left a stretch of extremely fertile alluvial plain between the two streams. It covers an area of I0,000 square kilometers, with less than 40 per cent of the total area arable. ${ }^{8}$ Due to the arid weather and alkaline soil of Hetao, farming depended on irrigation, but the proximity of the Yellow River made irrigated agriculture possible, in contrast to other parts of Inner Mongolia - and north China - where dry farming prevailed. The irrigated land of Hetao was said to yield harvests ten times larger than those on the dry mountain lands south of the passes. ${ }^{9}$ Although the claim may be proverbial rather than literal, it indicates the

8. Feng Jilong (ed.), Diaocha hetao baogaoshu [Reports on the survey of Hetao] (Taipei, I97I), pp. 2-4.

9. Yao Xuejing (ed.), Wuynan tingzhigao [Draft gazetteer of Wuyuan sub-prefecture], 2 vols (Yangzhou, I982), II, p. 7 . 
extraordinary fertility of the alluvial soil as compared to the dry land of north China. Further, the Yellow River provided cheap water transportation that linked the area to downstream markets in Baotou, Hekou, and beyond.

Administratively, Hetao was located at the intersection of three Mongol banners: the Dalad and Hanggin banners of the Ikh Joo league and the Urad banner of the Ulaanchab league. Its geographical isolation and marginality, far from any political, religious, or market centers, made it a weak link in the traditional form of Manchu-Mongol political control. None of the headquarters of the Mongol ruling princes were located within its boundary. Prior to the twentieth century, Han settlers in Hetao were under the jurisdiction of a Beijing-dispatched commissioner based in Shenmu county of Shaanxi province, and a sub-prefect at Salaqi who answered to the administration of Shanxi province, both residing outside the region. The political vacuum thus left ample room for the growth of a vigorous local autonomy.

Thus far we have analyzed the natural and social conditions that prepared the stage for the irrigation boom of Hetao: capital drawn from the Han-Mongol trade, cheap labor supplied by the influx of Han migrants, cheap land obtained from the Mongols, water provided by the Yellow River, and the negligible presence of an intrusive state. While these structural factors are indispensable in understanding the economic development and social transformation in Hetao, social actors played an equally significant role. The following section illustrates the first economic boom in Hetao during the first half of the nineteenth century, and the role played by the group of Han entrepreneurs who invested merchant capital in irrigation systems and organized commercial agriculture.

\section{RISE OF LAND MERCHANTS}

Compared with the areas adjacent to the Great Wall, farming in Hetao began rather late, owing to its geographical isolation and the capricious nature of the Yellow River. The area remained a marshy flood zone till the river settled in its present course in 1850 , and it was not until the early I 800 s that a group of Han merchants from nearby Baotou began to penetrate the area to barter with the local Mongols. By this time, the Mongols at large had been exposed to a monetized economy brought by Chinese trade, while the extravagant lifestyle of the aristocracy further made them easy prey to usurious moneylending. In Hetao, the merchants soon began to acquire the land that the Mongols put down as security and put it under irrigation. Because of their heavy involvement in land development, they were known as land merchants. Most members of this group were long-distance traders from the neighboring provinces of Shanxi and Shaanxi, but artisans and demobilized officers from other parts 
of China also entered the trade. Together they created a highly commercialized, capital-intensive, profit-oriented form of agriculture that departed from the traditional mode of production centred on small peasant family farms. Within decades, Hetao was turned from a pastoral hinterland into one of the most prosperous agricultural zones outside the Great Wall.

Much of what we know about land ownership and irrigation patterns in Hetao comes from the early twentieth century, when the government measured land and canals in preparation for their confiscation. In 1902, the Qing court changed its age-old protective policy toward the Mongols in favor of one that promoted active reclamation of their lands, as part of the New Policies reform that aimed at modernizing the empire. Its primary purpose was to raise funds to pay the colossal Boxer indemnities as well as cover the expenses of various reform programs in education, administration, and the military. During the official campaign, all the private canals of Hetao were expropriated, and the owners were obliged to report to the Qing authorities the details of each canal. These statements, preserved in the unpublished Archives of the Imperial Commissioner for the Reclamation of Mongol Banner Land (Qinming duban mengqi kenwu dachen, 1902-1911) in the Archive of Inner Mongolia, offer first-hand data on the irrigation systems of Hetao and their developers.

The following statement of two Shaanxi firms, Yongshengxing and Jinyonghe, described the circumstances surrounding the opening of Chanjindi (Mongolian: Chayija boro tala, in today's Bayan Noor league of Inner Mongolia), which marked the official inauguration of Han reclamation in Hetao. ${ }^{\circ}$

Yongshengxing and Jinyonghe, land merchants of Chanjin, testified as follows: In the fifth year of the Daoguang reign [1825], due to the silver owed our shops, Dalad banner consulted the Lifanyuan about opening Chanjindi of Houtao as repayment, and the request was granted. At the time, the land lay in wilderness, over roo li away from the Yellow River. Our shops set out to build a small canal that extended for 170 or $180 \mathrm{li}$ from the [Yellow] River in the south to Bulong-nao'er in the northeast. We hired workers to dig the channel and dredge the bed, and it took several years and cost a fortune for water to reach the fields. The land, then covered with lush grasses, had to be cleared and weeded before farming could begin. Over the years, although the proceeds cancelled part of the debts, the banner still owed our shops a capital of 50,000 taels of silver, interests excluded. Account books are available for verification. ${ }^{\text {I }}$

I. Zhao Erxun et al. (eds), Qingshigao [Draft of Qing History], 48 vols (Beijing, I977), vol. 47, p. 14375 .

II. Qinming duban mengqi kenwu dachen quanzong dang'an [Complete archives of the Imperial Commissioner for the reclamation of Mongol banner land] [hereafter, KWDC], 536 
The statement shows how the indebtedness of the Mongol aristocracy facilitated Han agricultural expansion. In this case, the prince of Dalad banner agreed to open a large block of land for cultivation in repayment of his debt. Along with the land rights, the firms also obtained water concessions. The Chanjin canal, built in 1825 , was one of the earliest irrigation systems developed in Hetao.

The statement of another firm, Xiechenghe, provides more details on landholding and irrigation-related costs during the I820s:

My grandfather obtained a tract of land from Dalad banner, a total area of over 2,500 qing. From the second year of the Daoguang reign [1822] through the fourth year [1824], he developed the Gangmu Creek canal, with over I00,000 taels of silver spent on labor costs. The intake is $7 \mathrm{zhang}$ wide and $7 \mathrm{cbi}$ deep, and the end is 5 zhang wide and 5 chi deep. The entire project is between 170 and $\mathrm{I} 80 \mathrm{li}$ long. [...] It irrigates over 3,000 qing of area, including our own land and that of others. [...] Dykes were built to protect the crops from floodwater. Each year, over Io,000 taels were spent on labor costs for repairing the dykes, and another 10,000 taels for dredging the bed. The water fee payable to Hanggin banner was convertible to two boxes of brick tea and twenty pairs of leather boots. Over the years, around 80,000 taels of silver had been lent to Dalad banner. Account books are available for verification. ${ }^{\mathrm{I}}$

Like the two other firms, Xiechenghe acquired over 16,600 hectares of land from Dalad banner as repayment of a loan of 80,000 taels. It should be noted that the land was obtained through leasing rather than outright sale, with an annual rent in cash or kind paid to the Mongol banner. In addition, a small water fee was payable in kind to Hanggin banner, through which territory the water route ran. These expenses, however, were negligible compared with the labor expenses of the canal which cost I00,000 taels to build and another 20,000 taels per year to maintain. This was because the heavy sediment of the Yellow River made it necessary to dredge the bed and strengthen the dykes regularly so as to prevent silting up and protect the fields from floodwater.

These statements demonstrate several facts about agricultural development in Hetao in the early nineteenth century. First, in Hetao, unlike other peripheries, it was merchant-entrepreneurs rather than farmers who initiated the Han agricultural advance. Agriculture, from the very beginning, was part of the commercial transaction involving capital, land, and labor. Second, the endorsement of the Lifanyuan testified to a slackening of the Qing policy due to diminishing strategic concerns in the

juan, group no. 433 , vol. I06, no. 20. I $l i=0.5 \mathrm{~km}$. The tael (liang) is a unit of weight measurement and the basis of silver currency in China and other east Asian countries. One tael was roughly equivalent to $38 \mathrm{gm}$ ( $\mathrm{I} .33 \mathrm{oz}$.).

I2. KWDC, vol. 106, no. 23. I qing $=6.667$ hectares; $\mathrm{x}$ zhang $=10$ chi $=3.2$ meters. 
northern frontier. The Mongol elites were thus allowed greater freedom to ease their economic burden and generate income out of their hereditary land which was theoretically unalienable. Third, the natural conditions of Hetao created a high bar for irrigation development, which demanded significant capital investment on not just initial construction but also regular maintenance. All these set the merchants of Hetao apart from their kind elsewhere.

Canal building, as we have seen, was a laborious and expensive task. The colossal expenses often turned out to be beyond the means of individual firms, thus making collaboration necessary. The following statement details the cooperation between two firms:

In the eighth year of the Daoguang reign [1 828], this firm, named Yongshenghe, acquired a tract of land from Dalad banner. At the time, a total of 1,500 taels and 96 ounces of silver and 2,000 strings of copper coins were paid to Dalad banner. We cut a separate water route of the Gangmu Creek canal through Hanggin territory, which cost over 8,000 taels of silver to build. Xiechenghe undertook to finish the Gangmu Creek canal from the Yongshenghe canal through the end. [...] From the twenty-third year of the Daoguang reign [1 843] on, other firms also concerted their efforts in dredging the canal. We own a branch canal that functions till this day. ${ }^{\mathrm{I}}$

The statement testified to a form of simple partnership in irrigation development. As the Gangmu Creek canal silted up, Yongshenghe set out to cut a new intake and link it to the lower reach of the canal that was undertaken by Xiechenghe. The two firms built their sections separately but became joint owners of the canal through a partnership, with more firms chipping in to cover the maintenance costs after i 843. Meanwhile, individual firms began to develop private branches that extended from the trunk canal to their individual plots.

A similar form of partnership was organized in operating the Chanjin canal. Initially built by the partnership of two firms, it later passed into a multiple shareholding system. As the local gazetteer of Linhe county notes, a relatively sophisticated system of financing and organizing irrigation existed in Hetao in the first half of the nineteenth century, in which all irrigation related affairs were resolved through public discussion attended by all shareholders:

During the Daoguang [1821-1850] and Xianfeng [185I-I86I] periods, the [Chanjin] canal was jointly operated by forty-eight land merchants. The current Gongzhong Temple, built on a magnificent scale with collective funds, used to

I3. KWDC, vol. 352, no. 5. The copper coin (qian) was usually counted by strings (diao), i.e. $\mathrm{I}, 000$ coins (wen). A string of $\mathrm{I}, 000$ coins was supposed to be equal in value to one tael of silver. However, its conversion rate with silver in the late I890s in Hetao was around 2,000 coins for one tael of silver. 
be their assembling place. At the time, the merchants rented land from Mongol banners that stretched over a large area and relied on the [Chanjin] canal for irrigation. They cooperated closely in its yearly maintenance and repair works, each contributing according to his share. No doubt a community of common interest has taken shape. ${ }^{14}$

As we can see, the necessity to pool resources created a densely connected yet relatively egalitarian community based on shared interests and responsibilities. The result was quite remarkable: during the i 850 , the Chanjin canal alone irrigated an area of between 20,000 and 26,700 hectares, with an annual yield of hundreds of thousand shi of grain. ${ }^{\text {Is }}$

This economic boom, however, was cut short by the Hui Muslim Uprising and its Qing suppression (I862-I 877). During the suppression campaigns, the market town of Chanjin served as a supplying center for the Qing troops in Shaanxi and Gansu. The merchants were mobilized to transport military supplies and organize local militia to defend the locality against the rebels, resulting in the neglect of irrigation works. The exaction of the army, which garrisoned in Chanjin for three years, was followed by the rampage of "mounted bandits" (mazei) in I 876 that devastated the local economy. In its aftermath, businesses were nearly wiped out, and farm estates were in ruins or deserted. ${ }^{16}$ The economic decay was manifest from the sharp decline of annual income of Dalad banner, which shrank from I00,000 taels of silver in the I 850 s to less than 3,000 strings of copper coins in the I870s. ${ }^{17}$

\section{REVIVAL OF IRRIGATION ECONOMY}

The end of the mid-nineteenth-century crisis brought yet another economic boom in Hetao. The second stage, spanning from the i 870 s through the turn of the century, departed from the earlier period in terms of geographical locus, organizational format, and degree of commercialization. Whereas Han settlement of the first stage was concentrated in the town of Chanjin in north-western Hetao, the second stage saw a shift of economic gravity to eastern Hetao, notably the market town of Longxingchang (present Wuyuan county of Inner Mongolia). While irrigation in the first stage was organized on the basis of simple partnerships (penghuo), the second stage saw rapid irrigation expansion through a more inclusive

I4. Wang Wenchi, Linhe xianzhi [Local gazetteer of Linhe county] (Taipei, I968), pp. I 30-I33.

I s. Ibid. Shi (or dan) is a grain capacity measurement unit in China. I shi=60 kg.

I6. For the impact of Hui Uprising on Hetao, see Zhao, Qingshigao, vol. 47, pp. I4371-I 4372, I4376-I4377. For a general account on the Uprising, see Jonathan N. Lipman, Familiar Strangers: A History of Muslims in Northwest China (Seattle, WA, 1997).

17. Zhao, Qingshigao, vol. 47, p. I4378; Suiyuan Tongzhiguan (ed.), Suiyuan tongzhigao [Draft annals of Suiyuan], I 2 vols (Hohhot, 2007), V, pp. 589-590; Wang, Linhe xianzhi, p. I3 I. 
shareholding (penggu) arrangement in which shares were offered to those who provided not just capital but also expertise and labor. Moreover, the second period was characterized by growing commercialization of land and labor, with a greater degree of integration with the regional and global economic system.

A set of historical and social circumstances contributed to the second economic boom in Hetao. On the domestic front, massive rebellion, war, and famine punctuated the I860s and I870s: first the Hui Muslim Uprising and its suppression that devastated north-west China and the adjacent Mongolian periphery, immediately followed by the great famine of $1876-1879$ that caused the death of $9-13$ million people in north China. ${ }^{18}$ The social turmoil, nevertheless, also brought new opportunities. The necessity to supply the Qing troops and expand fiscal revenue during the expeditions resulted in a further slackening of the ban on Han cultivation, especially in Hanggin banner that remained hitherto uncultivated. ${ }^{19}$ The warfare also brought new settlers, among whom were a group of demobilized officers from southern China who made fortunes during the military campaigns. Attracted by the economic opportunities in Hetao, they began to invest in irrigation works and soon rose to power in their contest for land and water. At the same time, the social unrest and natural disasters drove large waves of refugees from north China into the grasslands. In I 876, the ban against Chinese women outside the Great Wall was lifted by the Qing court, spurring the process of migration into Inner Mongolia and Manchuria. These new immigrants supplied cheap labor for the irrigation systems and farm estates of land merchants. Further, the soaring grain prices in the wake of catastrophes made crossregional grain trade prosperous, thus lending great impetus to the commercial agriculture in Hetao.

On the international front, the series of unequal treaties signed between China and the Western powers in the wake of the Second Opium War (I 856-I860) increasingly absorbed China and its peripheries into the global framework of capitalism and nation-states. The opening of Tianjin as a treaty port increasingly turned Mongolia into a sourcing ground of animal skins, wools, and medicinal herbs, which were in great demand on international markets. The treaties also opened up the entire QingRussian frontier to trade, as well as allowing Russian merchants the privilege of carrying out duty-free trade across Mongolia and Xinjiang, thus giving them an edge on their Chinese competitors in these regions. In Hohhot, Chinese firms suffered great loss on Bohea tea because of the

I8. Kathryn Edgerton-Tarpley, Tears from Iron: Cultural Responses to Famine in NineteenthCentury China (Berkeley, CA [etc.], 2008).

19. Wang Zhe, "Hetao qudao zhi kaijun yange" [Evolution of irrigation construction in Hetao], Yugong banyuekan, 7:8 and 7:9 (1937), p. I24. 
competition from the Russians, and the markets of cotton textiles there were completely dominated by foreign manufactures. ${ }^{20}$ Meanwhile, the opening of the Suez Canal in I 869 and the construction of modern railways caused the trade routes to shift, eventually resulting in the decline of the caravan trade overland. Foreign competition and introduction of modern means of transportation thus led some Chinese firms to redirect their investment from traditional lines of trade of tea and cotton cloth into the more profitable grain trade, thus spurring the commercialization of grain production.

With capital and labor flowing into Hetao in the i870s, an economic surge was under way. By the early i90os, irrigation networks in Hetao consisted of 8 major canals and around 40 minor ones, which added to a total length of nearly $800 \mathrm{~km}$ and covered an irrigated area of over 72,000 hectares. ${ }^{2 I}$ In just a few decades' time, Hetao became one of the most important grain-producing areas outside the Great Wall, with an estimated annual yield of over 100,000 tons of grain, enough to feed half a million people. ${ }^{22}$ A local saying highlights the extraordinary prosperity of Hetao in contrast to the disaster-prone lower reaches: "The Yellow River brings a hundred disasters; it bestows prosperity only on the loop" [buanghe bai hai, wei fu yi tao].

Table I shows basic information on the eight major canals that survived into the twentieth century. Each of these trunk canals (ganqu) supplied a hierarchical system of branches (zhiqu) and sub-branches (ziqu) that provided water to individual plots.

In 1904, as part of the official reclamation campaign, the Qing authorities expropriated all private canals of Hetao, with the owners receiving a small amount of money - usually Io per cent of the original costs - in compensation. To be eligible for compensation, the owners had to provide details about the canals, such as builder, year of construction, location, scale, and cost. As of 1907 , a total sum of 72,175.65 I taels of silver were paid to 38 parties in return for the 44 canals confiscated, with the amount each received varying from 100 to 10,000 taels. $^{23}$

20. A. M. Pozdneyev, Mongolia and the Mongols, 2 vols (Bloomington, IN, I977), II, p. 49. 21. Zhang, "Lüelun hetao dishang", p. 91. The major canals were typically over $50 \mathrm{~km}$ long, IO-I 6 meters wide, and I.3-2 meters deep. The minor canals were usually less than $25 \mathrm{~km}$ long. See Wang, "Hetao qudao zhi kaijun yange", pp. I23-I I.

22. The yield is calculated based on J.L. Buck's report of 24 bushels (c.653 kg) of wheat per acre on irrigated land in north China, multiplied by the arable land of Hetao. See John Lossing Buck, Land Utilization in China: A Study of 16,786 Farms in 168 Localities, and 38,256 Farm Families in Twenty-two Provinces in China, 1929-1933 (Chicago, IL, 1937), p. 233. For an estimation of a similar figure, see Zhang, "Lüelun hetao dishang", p. 91.

23. Inner Mongolian Archive Bureau (ed.), Qingmo neimenggu kenwu dang'an huibian [A collection of archives on reclamation in Inner Mongolia during the late Qing], (Hohhot, 1999), pp. $142 \mathrm{I}-\mathrm{I} 422$. 


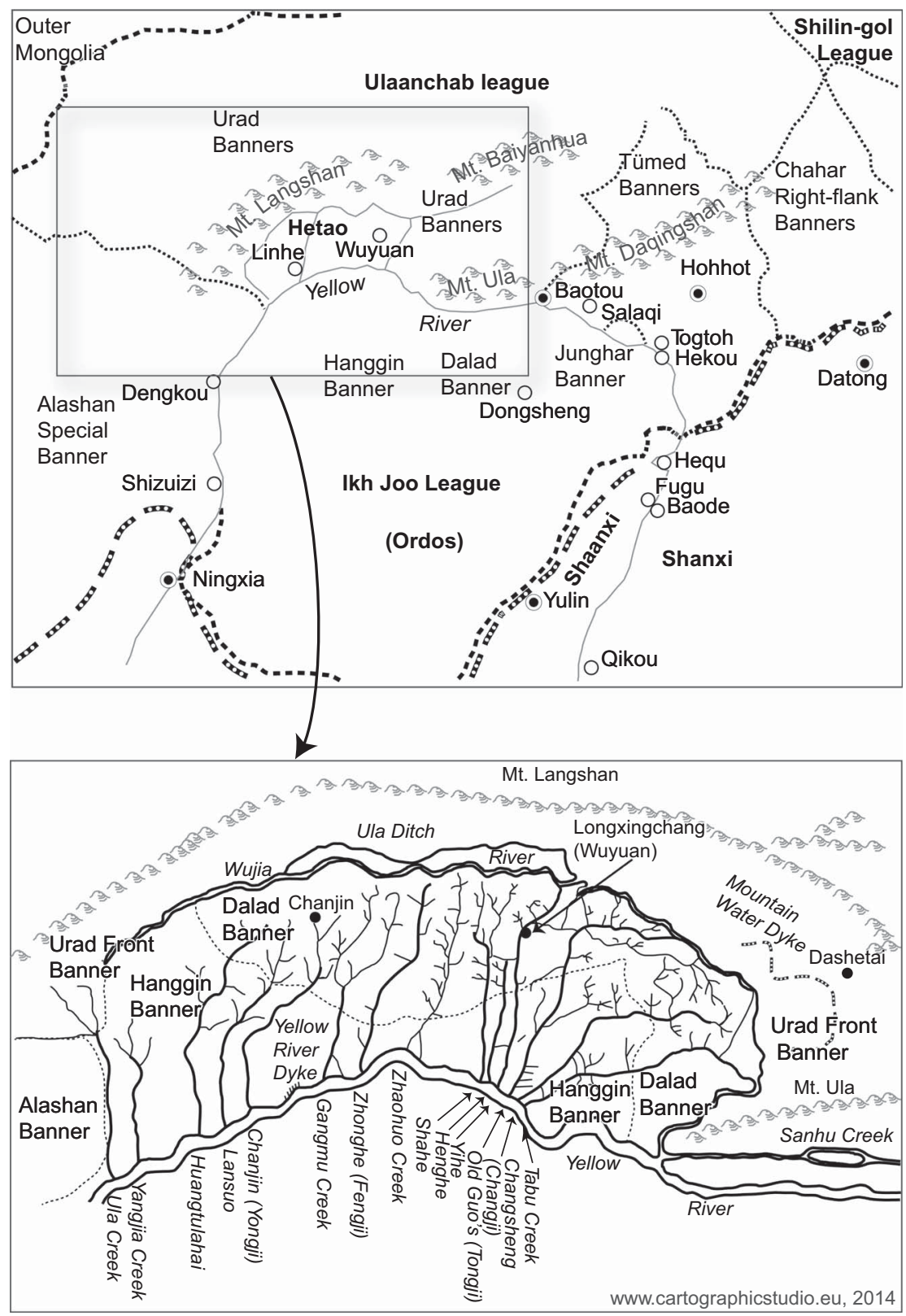

Figure 2. Location of Hetao and the major canals of Hetao (early igoos).

An analysis of these first-hand data reveals some general trends of irrigation development in Hetao. The vast majority of canals - 4I out of 44 - were built after the crisis of the I86os, including 6 out of the 
Table I. Eight major canals (as of 1904).

\begin{tabular}{|c|c|c|c|c|c|}
\hline Name & Year & Builder & $\begin{array}{l}\text { Length } \\
(\mathrm{km})\end{array}$ & $\begin{array}{l}\text { No. of } \\
\text { branches }\end{array}$ & $\begin{array}{l}\text { Irrigated area } \\
\text { (square } \mathrm{km} \text { ) }\end{array}$ \\
\hline Gangmu Creek & 1822 & Xiechenghe, Yongshenghe & 65 & 12 & 67 \\
\hline Chanjin & 1825 & Yongshengxing, Jinyonghe & 75 & 6 & 200 \\
\hline Old Guo & 1866 & Wandeyuan, Wantaigong, Shi Laohu, Guo Dayi, Guo Minxiu & 51.3 & 27 & 100 \\
\hline Changsheng & 1872 & Hou Shuangzhu, Zheng He, Hou Yingkui, Dehengyong & 54.5 & 21 & 120 \\
\hline Tabu Creek & 1875 & Fan Sanxi, Xia Mingtang, Cheng Shunchang, Gao Hewa, Ji'erguqing & 60 & 21 & 113 \\
\hline Yihe & 1880 & Wang Tongchun & 57.5 & 4 & 106 \\
\hline Yonghe & 1891 & Wang Tongchun & 45 & 10 & 73 \\
\hline Zhonghe & 1899 & Wang Tongchun & 48 & 5 & 67 \\
\hline
\end{tabular}

Sources: Han Meipu, Suiyuan sheng hetao diaocha ji (Höhhot, 1934); Feng Jilong, Diaocha hetao baogao shu (Taipei, I97I); Wang Zhe, "Hetao qudao zhi kaijun yange", Yugong banyuekan, 7:8 \& 9 (1937), pp. I23-I I; Zhou Jinxi, Suiyuan hetao zhiyao

(Letterpress copy, 1924); Chen Erdong, Hetao guanqu shuili jianshi (Beijing, 1988). 
8 major canals. At the time of confiscation, 32 were still owned by their builders or their first-generation descendants, showing a significant surge of irrigation development in the final decades of the nineteenth century. Compared with the earlier period, the number of single-owned canals increased distinctly, due partly to the proliferation of smaller-size canals, and partly to the growing trend of consolidation. This can also be seen from the naming of the canals. While the earlier canals were typically named after places, the newer ones usually bore the name of a single investor, be it a firm (e.g. Heheyuan), a lineage hall (e.g. Changxingtang), a family clan (e.g. Caojiadi), or a person (e.g. Old Guo). Out of the 34 canals that were single-owned, 26 were minor ones or branches that were less than $25 \mathrm{~km}$ long. This may be explained by the opening of the hitherto uncultivated land of Hanggin banner adjacent to the Yellow River, which made minor canals a more affordable option for developers. Further, the influx of Han settlers also made fragmentation and subdivision of irrigation systems necessary.

Meanwhile, there was a countervailing tendency toward concentration of ownership, with some owners buying out others. This can be seen from canal names such as Sidagu, Wudagu, and Shidagu (meaning "Four/Five/ Ten-big-shares"); while the names indicated the corporate origin of these projects, they eventually became single-owned, showing a brisk tendency of privatization and consolidation. Further, the preponderance of technology in irrigation development also played a part, which allowed technical experts to capitalize on their expertise and accumulate wealth, as seen in the case of Wang Tongchun, who singlehandedly developed three of the eight major canals in Hetao.

\section{A SHAREHOLDING SYSTEM}

While the rise of single ownership testified to a tendency of privatization in irrigation development, this was largely applicable to smaller-scale canals. Meanwhile, partnership-owned projects continued to thrive during the second period, as the scale of larger projects often made collaboration necessary. Compared with the simple partnerships in the earlier period, which were typically formed among fellow countrymen or close friends, the shareholding system of the second period was more complex and elaborate. Shares now became fully alienable; they could be split, bought, and sold, and also be acquired through investment of expertise, labor, or land.

The shareholding system was developed by the trading and banking firms of Shanxi merchants in the early nineteenth century, and gained popularity among the canal developers from the I860s. ${ }^{24}$ Under this system, each 
shareholder obtained a certain amount of shares according to his investment, typically expressed in Io-per-cent $(f e n)$ or I-per-cent (li) units. Benefits (li) and duties (hai) were distributed proportionately among shareholders. Apart from irrigating their own plots, shareholders may also sell water rights to others or rent them out for a fee. Meanwhile, they were responsible for paying their allotment of labor costs, in proportion to the area of irrigable land they possessed. Like other forms of property, shares were inheritable and transferrable. It was also possible to divide the shares into smaller proportions, with branches developed and owners of new sections sharing in the costs of trunk maintenance.

The shareholding system was reinforced by devices such as written agreements and the building of temples. Partnership contract (behuoyue) established the terms of shareholding by specifying the rights and responsibilities of each partner. It was primarily private, signed in the witness of two to four middlemen that included Han and Mongols. The contract helped ground economic transactions in a set of social relations and customary practices, thus facilitating the process of commercialization..$^{25}$ Apart from the contract, temples were sometimes erected as an inculcation of religious and symbolic bonds among shareholders. The stele inscription of the renovated Sidagu Temple showed that it was first built to commemorate the partnership of the original four big shareholders. ${ }^{26}$ Temples provided a public space for discussing irrigation-related affairs as well as staging public rituals and festivities, thereby embedding the economic practices in social and symbolic terms.

The following contract provides more detail on the terms of shareholding:

The merchants residing in the vicinity of the Gangmu canal, troubled by its siltation and unable to expand it on their own, have decided to collaborate with Dalad banner in widening and deepening the channel from the intake to the end. In terms of expenses, the banner is to take charge while the merchants contribute. Those who have money should contribute money, and those who have not should offer their land to cover the duties. From the intake to the end, wherever water is accessible, duties are applicable to the land. It is determined that each qing of land is equivalent to fifty thousand copper coins of labor costs

merchants elsewhere in China, see Madeleine Zelin, "Capital Accumulation and Investment Strategies in Early Modern China: the Case of the Furong Salt Yard", Late Imperial China, 9 (1988), pp. 79-I22; Kenneth Pomeranz, “Traditional' Chinese Business Forms Revisited: Family, Firm, and Financing in the History of the Yutang Company of Jining, 1779-1956", Late Imperial China, I 8 (1997), pp. I-38.

25. For the use of contracts in late imperial China, see Myron L. Cohen, "Writs of Passage in Late Imperial China: The Documentation of Practical Understandings in Minong, Taiwan", in Madeleine Zelin et al. (eds), Contract and Property in Early Modern China (Stanford, CA, 2004), pp. 37-93.

26. Yao, Wuyuan tingzhigao, II, pp. 43-46. 
incurred by the canal, on top of the land proceeds payable to the banner. Once the duties are paid in full, the land should be returned to its holder. Water is to flow unblocked, and allotments should be paid in proportion to the shares. Dalad banner may freely dispose of any land without holder. Should any dispute on the canal arise, it will be taken care of by Deputy Administrator Mantou. Lest words have no guarantee, this contract is made in witness whereof. ${ }^{27}$

Here we see an example of joint ventures between Han merchants and Mongol elites in irrigation development, as the shareholding system allowed the latter to acquire shares in return for land. In this case, the deputy administrator of Dalad banner served as guarantor and nominal head for the irrigation project, and received a share in the canal, as well as the right of freely disposing of any unleased land that would potentially benefit from the project. This was by no means an isolated case. Several Mongols were listed as canal contributors during the official reclamation campaign, among whom were Ji'erguqing of Dalad banner, one of the five big shareholders of Tabuhe canal, and Lieutenant Officer Changhanbuluo of Hanggin banner, who offered two canals located within the boundary of his assigned household plot to the Qing authorities. ${ }^{28}$

The merchants in turn were responsible for any applicable duties incurred by the construction and future maintenance of the canal. In lieu of capital, one might also offer land in payment, at a rate of 50,000 copper coins (equivalent to 25 taels of silver) per qing. ${ }^{29}$ On top of that, rent was due to Dalad banner as usual. Once the due amount was cleared, the land would be returned to its original holder. What was involved here was in fact conditional sale of the right of use of land, showing a higher degree of land commodification as a result of its potential increase in value with irrigation. Here we see an arrangement in which irrigation was financed by offering shares to those who provided capital, land, and political support. According to the contract, the water route must not be blocked so as to ensure equal access to water for all shareholders. At the same time, duties should be distributed according to one's respective share, in proportion to the area of irrigable land one possessed. Hence the larger the area, the greater the share of duty payment as well as the benefits brought by water.

27. KWDC, vol. 244, no. 9 .

28. KWDC, vol. 244, no.7. Household lands were allocated in several Ordos banners in the I 860 s, as a reward for the Mongol soldiers who contributed to the suppression of the Hui Muslim Rebellion. See Anzai Kuraji, "Mōkyō ni okeru tochi bunkatsu shoyūsei no ichi ruikei: ikokushō mei junkatsujiki gatōchi ni okeru tochi kankei no tokushitsu” [A type of divided land ownership in Mongolia: features of land relations in Hetaodi of Jungar banner of Ikh Joo League], Mantetsu Chōsa Geppō, 22:5 (1942), pp. 31-98, 53.

29. The copper cash was usually counted by strings (diao), i.e. I,০oo coins (wen). Its conversion rate with silver in the late 1890 s in Hetao was around 2,000 coins for I tael of silver. 
Contracts were also used to settle disputes over water use, as seen in the following contract regarding the Sidagu canal:

\begin{abstract}
Wandeyuan, Demaoyong, Wantaigong, and Gongyiyuan hereby conclude the below contract as evidence. In the ninth year of Tongzhi reign [1870], Wandeyuan cut a canal from Tuchengzi and linked it to the old creek of the Yellow River to irrigate the land of Mangesutai. In the twelfth year [1873], Gongyiyuan cut a canal from the old creek of the River to irrigate the land of Halinjiaba Monastery. No previous agreement was made regarding the amount of water to be used. In the fourth month of the second year of the Guangxu reign [1876], the matter is being settled through mediation of middlemen, and the two parties voluntarily agree that from now on, for using the shared water route, Gongyiyuan is to pay Wandeyuan 600 strings as water route fee and 400 strings as construction fee for the canal and dykes. Henceforth, all expenses incurred by the building of Tuchengzi canal as well as repairing of the Dingtou dykes should be divided into four equal shares. Once water reaches the old creek of the River, each shareholder may cut openings and build their own branches. Water is to flow unblocked; no dams should be made inside the canal. From now on, Gongyiyuan is allowed to use water only for irrigating its own plots; selling water rights to outsiders for a fee is prohibited. Lest dispute arises in the future, we hereby conclude a written contract as evidence. ${ }^{3 \circ}$
\end{abstract}

The contract testified to the growing competition among canal developers due to the commodification of water. Gongyiyuan, which owned a downstream branch canal, had been selling water rights to lower-level users without the permission of upstream developers, while the latter dammed up the canal in response. The scenario was common between owners of trunk and branch canals, or between upstream and downstream users of the same canal, often resulting in feuds and armed conflicts. Under such circumstances, shareholding provided a means to settle such disputes by offering shares for purchase and turning competitors into partners. After mediation, Gongyiyuan agreed to pay I,000 strings of cash to Wandeyuan, forfeit its right of selling water to outsiders, and help cover any future costs incurred, in exchange for a share in the Sidagu canal.

However, contracts were not always binding. It often took multiple rounds of mediation, negotiation and contract-signing to settle a dispute. After the initial contract was signed in I876, Gongyiyuan clashed again with an employee of Wandeyuan, and accordingly refused to pay the agreed sum while continuing to sell water to outsiders. To resolve their quarrels, a second contract was drawn up in I880, which reiterated Gongyiyuan's obligation to pay its due and refrain from water selling. As a penalty, the new contract granted Wandeyuan the right to dam up the Gongyiyuan canal for ten days in the autumn, which was an open breach of the principle of equal access to water by all shareholders. It was not 
until after a third round of mediation in 1883 that the matter was closed, with Gongyiyuan made to pay an additional sum of 350 strings to Demaoyong and Wantaigong, in exchange for Wandeyuan forfeiting its extra water rights over the Gongyiyuan canal. ${ }^{3 \mathrm{I}}$ All this showed the limitation of shareholding entailed by inadequate legal enforcement. The multiple contracts indicated a dynamic process of power negotiation among shareholders that was grounded in customary practices rather than adjudication of the state.

The shares were not acquired through financial investment alone. Shanxi merchants traditionally divided the shares in their trading and banking firms into two types, "monetary" shares (caigu) obtained through capital investment and "corporeal" shares (shengu) granted in honor of special contributions by founders and managers. In canal building, shengu shares were offered to technical experts and skilled workers for the expertise and labor they provided, in lieu of most of the wages they would otherwise be owed. ${ }^{32}$ This was because irrigation demanded not only considerable capital input, but also knowledge, expertise, and experience. To prevent silting up and ensure proper water flow, it was crucial to choose the location of the intake carefully, design the route, and build sluiceways to carry off surplus water. Technical details such as these were often neglected by previous builders, resulting in not only waste of time and resources, but also severe flooding and even the financial ruin of the owner.

The shareholding system thus provided opportunities for upward mobility of those who possessed expertise but little capital. The most prominent example was Wang Tongchun (I 85 I-I925), a native of Xingtai county of Zhili who became the self-made "King of Canals" in Hetao. At the age of twelve he left home for Dengkou in Alashan banner on the left bank of the Yellow River, to work in a leather workshop owned by a kinsman. There he acquired hydraulic skills from observing practitioners from Ningxia, where irrigation dates back to the Eastern Han Dynasty $(25-220 \mathrm{AD})$. Later he was hired as overseer of the Sidagu canal and acquired a shengu share through his service. At age thirty, Wang set out to build his own canal, after leasing land from a local monastery. In two decades, he completed four major canals - Yihe, Yonghe, Henghe, and Zhonghe - and became the wealthiest land merchant in Hetao. ${ }^{33}$ Much of Wang's success was attributable to his skills as a hydraulic engineer.

3I. KWDC, vol. 285 , no. I

32. KWDC, vol. I 54 , no. I 2 .

33. Gu Jiegang, "Wang Tongchun kaifa hetao ji" [On Wang Tongchun's development of Hetao], Yugong banyuekan, 2:I 2 (1935), pp. 2-10; Wang, Linhe xianzhi, II, p. 29; Su Xixian, "Wang Tongchun - Hetao shuili kaifa de jiechu rencai" [Wang Tongchun: mastermind in irrigation development in Hetao], in Committee of Cultural and Historical Data of CPCC Inner 
The stele inscription of the Sidagu Temple compared him to legendary figures like King $\mathrm{Yu}$ and $\mathrm{Li}$ Bing who were renowned for taming rivers and creating irrigation systems in ancient China. ${ }^{34}$ After his death in I925, Wang was worshipped as River God, with a temple dedicated in his memory, and ritual services were held on the anniversary of his death and during periods of drought or flood. ${ }^{35}$

Thus far we have analyzed the role of land merchants as entrepreneurs investing in and organizing irrigation works of Hetao. As we have seen, shareholding enabled an alliance of capital, expertise, labor, and land in irrigation, thereby lending a great degree of efficiency and flexibility to the system. In what follows, we shall discuss their role as landlords, with a focus on their relations with the Mongols and Han peasants and rural workers.

\section{COMMERCIALIZATION OF LAND RELATIONS}

Accompanying the commercialization of irrigation systems based on partnerships and shareholding was the growing commercialization and privatization of land during the second half of the nineteenth century, resulting in the separation of land ownership and actual land use, so that Mongol landowners were reduced to rentiers while Han settlers became actual landholders. Meanwhile, the development of commercialized land relations also resulted in distinct social stratification in the settler society, giving rise to wage labor in irrigation and agriculture.

The increasing commodification of land can be seen in the changing forms of rental payment. Early settlers in Hetao obtained land from the Mongols for a minimal rent in kind that varied from several dou to several sheng of grain per niuju (I 8 hectares). ${ }^{36}$ No purchase price was necessary, except for gifts offered to the landlord known as "personal favors" (bandi renqing). Over time, silver became the standard payment in land proceeds and fees, with qing replacing niuju as the standard unit of measurement. By the end of the nineteenth century, the rent charged by the Mongols

Mongolia Committee (ed.), Wang Tongchun yu betao shuili [Wang Tongchun and irrigation works of Hetao] (Hohhot, 1989), pp. 43-91, 57-59.

34. See Yao, Wuyuan tingzhigao, II, p. 45. King Yu (c.2200-2 100 BC) was a legendary ruler in ancient China famed for introducing flood control along the Yellow River. Li Bing was an administrator and engineer renowned for the construction of the Dujiangyan Irrigation System of Sichuan in 256 BC.

35. Gu, "Wang Tongchun kaifa hetao ji", p. ıо; Zhang Xiangwen, "Wang Tongchun xiaozhuan" [A brief biography of Wang Tongchun], in Nanyuan conggao [Collective works of Zhang Xiangwen], (Taipei, 1968), juan 7, pp. 52-53.

36. Niuju (yoke-of-oxen) refers to the area cultivated by one plough in a year's time, equivalent to 2.7 qing or 18 ha. See Ding Xikui, Jingbian xianzhigao [Gazetteer of Jingbian county] (Taipei, I970), pp. 291-292. I sheng $=$ IO dou $=0.1$ shi $=6 \mathrm{~kg}$. 
had risen to 4 or 5 taels of silver per qing, or the equivalent amount of copper coins. ${ }^{37}$ In addition, a one-time contract fee (yadiyin) was charged at the time of land leasing, plus water fees (shuiliyin) due to Hanggin banner, which were initially paid in the form of gifts and later converted into a standard payment of 50 taels per annum. ${ }^{38}$ All this showed a growing degree of monetization and integration of the Mongol society into the Chinese economy.

The centrality of irrigation in Hetao also triggered changes in the land regime and socio-technical arrangements. First, it gave rise to a land tenure called perpetual lease (yongzu), which allowed the lease holder to hold and make full use of the land for an indefinite period of time, on condition of rent payment. The holder was also free to pawn (dian), sub-lease $(z u)$, and transfer (tui) the land to others. It indicated an arrangement of conditional sale (dianmai), which differed from outright sale (juemai) in that the landowner retained the title and right of rent collection. This was to comply with the Qing laws that prohibited the sale of Mongol land, while protecting the long-term land use of the leaseholder. ${ }^{39}$ In effect, landowners became rent collectors while first tenants became de facto owners with full transfer rights. Eventually this arrangement led to the erosion of the hereditary, communal landownership of the Mongols by a privatized property regime that resembled those practiced in other highly commercialized parts of China, such as Taiwan and the Pearl River Delta. ${ }^{4}$

Second, the combination of extensive land and irrigation gave rise to largescale managerial farming based on massive capital accumulation and wage labor. What characterized the farm estates of Hetao was their extraordinary size, usually ranging from hundreds to over $\mathrm{I}, 000$ hectares in acreage.$^{4 \mathrm{I}}$ For example, the Beiniuju estate owned by Wang Tongchun, which was located on the lower reach of Yihe canal, covered over roo qing (667 hectares) of managerial farmland (niujudi) cultivated by hired hands and another 100 qing that was rented out to tenants. During the harvest season, threshing alone was done by some 300 hired hands, with bells used to coordinate their daily routines like clocking in and out and lunch breaks. ${ }^{42}$

37. Xibei kenwu diaocha ju (ed.), Xibei kenwu diaocha buice [Collected investigation reports on reclamation affairs of the northwest] (Taipei, I969), p. I I2.

38. KWDC, vol. I02, no. 2.

39. For a general discussion on the institution of perpetual lease, see Tayama Shigeru, Shin jidai ni okeru mōko no shakai seido [Social institutions of Mongolia in Qing period] (Tokyo, I954), pp. 226-227.

40. Cohen, "Writs of Passage in Late Imperial China: The Documentation of Practical Understandings in Minong, Taiwan"; Helen Siu, Agents and Victims in South China: Accomplices in Rural Revolution (New Haven, CT [etc.], 1989).

4I. Yao, Wuyuan tingzhigao, II, p.7.

42. Su, "Wang Tongchun - Hetao shuili kaifa de jiechu rencai", p. 83 . 
The institution of perpetual lease in Hetao in some ways resembled the multiple land-ownership regime found in southern China and Taiwan known as permanent tenancy (yongdian) or "one field, two owners" (yi tian er zhu), which was characterized by the separation of the "surface field" (tianmian) rights of the tenant from the "subsoil field" (tiandi) rights of the landlord. ${ }^{43}$ Both regimes were products of increasing privatization and commodification of land, and both protected the long-term usufruct rights of the landholder. However, there were also important differences between them. First of all, the yongzu system caused a shift of de facto ownership (from Mongol to Han) as well as changes in land use (from pastoral to farming), while no such change was entailed under the yongdian regime. Further, the yongzu system benefitted entrepreneurs engaging in large-scale land acquisition and development, whereas the yongdian regime favored small holders and tenant farmers by protecting their rights. Moreover, the yongzu system was developed through personal favors and oral agreements that were largely outside of state supervision, whereas the yongdian regime was secured by legal contracts under state regulation. The property regime in Hetao thus showed traits distinct from other parts of China, namely, the central role played by merchant-entrepreneurs in a frontier setting that enabled large-scale land development, and the preponderance of commercial capital in agricultural production.

The land merchants used a hierarchical structure to organize irrigation and land. At the center were a number of gongzhongs, which were central administrative units in charge of a canal or a section, depending on the size of the canal. The management of a gongzhong resembled that of a business firm, often with two layers of control. At the top level, a canal overseer was responsible for canal construction and water distribution, construction of dams, hiring of labor, and collecting of fees. As the estate grew, a further administrative level was put in place, with a manager supervising all general affairs, a bookkeeper in charge of accounts, a foreman responsible for handling land issues and for recruiting and managing labor, and several canal runners in charge of waterway patrols and fee collection. Depending on their performance, they would receive dividends on top of regular salary, usually in the form of land, which provided them incentives to optimize in irrigation and land management. ${ }^{44}$ Each gongzhong oversaw several niuju or smaller outlier settlements that resembled the villages of China proper. Most niuju, however,

43. It is notable that in Taiwan, the land rights held by the tenant were called "subsoil" rather than "surface" rights as in mainland China. For a detailed illustration of the one-field-twomasters regime in Qing Taiwan, see Wen-Kai Lin, "Land Property and Contract in Taiwan during the Qing and Japanese Colonial Period", unpublished paper.

44. Su, "Wang Tongchun - Hetao shuili kaifa de jiechu rencai", pp. 60, 82-83; Du Yasong, "Wang tongchun shilue" [A sketch of Wang Tongchun], in CPCC Inner Mongolia Committee 
were much more sparsely populated than a typical Chinese village, consisting of only a few households or sometimes even one. ${ }^{45}$ Such a hierarchical structure proved effective in organizing a settler community centering on irrigation.

What distinguished the gongzhong estates from other business firms, however, was that they not only controlled water, land, and labor, but also exercised a degree of judicial and policing authority in arbitrating disputes, providing security, and maintaining local order. We have mentioned that the indirect rule of the Qing government and the decline of nomadic society had created a power vacuum in this borderland, thus allowing the growth of a quasi-autonomous settler society. Many land merchants organized private militias to protect their estates, recruiting demobilized soldiers and vagabonds. These militias also kept an eye on workers and employees. As He Yangling points out, "In the old days, all civil and criminal affairs associated with farmers were determined by gongzhong, which functioned as a virtual government." ${ }^{36}$ In the absence of centralized control, the gongzhong estates formed a mechanism of economic mobilization and political control that in some ways resembled the plantation economies in the Americas.

As we have seen, the availability of large amounts of arable land acquired from the Mongols and cheap labor supplied by land-poor farmers and refugees from north China incentivized land merchants to organize large managerial farms using hired labor, instead of simply dividing the land into smaller plots for leasing. In an interview in 1919, Wang Tongchun claimed to have established a total of i 8 farm estates that covered over $\mathrm{I}, 000$ qing [6,670 hectares] of cultivated land, which comes to an average size of 370 hectares or more per estate. ${ }^{47}$ Another source shows that Wang's estates yielded over 230,000 shi of grain in an average year. ${ }^{48}$ If these figures are accurate, we would get an output of around $2.3 \mathrm{shi}$ per $\mathrm{mu}$, a figure nearly comparable to that yielded by a piece of prime irrigated rice land in east or south China. ${ }^{49}$ The high returns were all the more remarkable given the arid and

Wang Tongchun yu hetao shuili, p. 27; Han Xiangfu, "Wo suo zhidao de wang tongchun" [Wang Tongchun as I knew him], in Wang Tongchun yu hetao shuili, p. 98.

45. Qu Zhisheng, "Fuji er" [Appendix II], Yugong banyuekan, 4:7 (1935).

46. He Yangling, Chasui mengmin jingji de jiepou [An analysis of Mongolian economy in Chahar and Suiyuan] (Shanghai, 1935), p. I27.

47. Feng, Diaocha hetao baogaoshu, p. 263.

48. For the annual yield, see Wang Zhe, "Wang Tongchun xiansheng yiji" [Biography of Wang Tongchun]; Su, "Wang Tongchun - Hetao shuili kaifa de jiechu rencai", pp. 60, 69; Du, "Wang tongchun shilue", p. 28.

49. Li Bozhong estimates that the output of a piece of prime irrigated rice land in Jiangnan was between 2.4 and 3.6 shi per mu. See Li, Agricultural Development in Jiangnan, 1620-1850, p. 126. 
cold weather and short agricultural work year - from April to September - in Hetao as compared to those more accommodating areas. It was likely that these estates benefitted from professional management of irrigation works and a higher use of draft animals and natural fertilizer. For instance, Wang was said to have owned 3,100 cattle, I,700 mules, I 20,000 sheep, 500 camels, and 200 oxcarts and horse-drawn wagons. ${ }^{50}$ The diversity of animals indicated the supplementing of agriculture with animal husbandry and trade, something that characterized these estates other than their size.

Apart from organizing managerial farming, the land merchants also leased out significant proportions of irrigated land to renters. Wang Tongchun, for example, reportedly collected 170,000 taels of land rentals and water fees every year. ${ }^{5 \mathrm{I}}$ There were two types of land rentals: fixedrate leasing (fangzu) and sharecropping (banzhong). In the first case, the rate was determined after measuring the area where crops sprouted in the spring, and the rent usually ranged between 20 and 30 taels of silver per qing, payable in the autumn in cash or kind, regardless of actual yield. The tenants usually needed to provide their own draft animals, seed grain, and agricultural tools, and thus functioned as semi-independent farmers. Sharecroppers, in contrast, owned little or no means of production and had to depend on the landlord for their supply, and the harvested crops were shared with the landlord according to a predetermined rate. Depending on soil quality and capital input, the rate varied from a three-seven (three for landlord and seven for tenant) to a four-six or half-half distribution. ${ }^{22}$

Most settlers of Hetao were from Baode prefecture and Hequ county of Shanxi, with Fugu county of Shaanxi coming next, followed by Zhili and Henan. Settlers were divided into two hierarchical groups according to their social and economic positions: merchants and peasant proprietors vis-à-vis tenants and rural workers, set apart by their landholding capacity and ability to gain access to irrigation. Whereas the former were landholders who leased land directly from the Mongols and invested in irrigation works, the latter either rented land from the proprietors or sold their labor for wages. Their migration pattern also differed: while the former tended to reside in the area for extensive periods, the latter typically arrived in the spring and departed in the autumn, drifting from place

50. Wang, "Wang Tongchun xiansheng yiji" [Biography of Wang Tongchun]; Su, "Wang Tongchun - Hetao shuili kaifa de jiechu rencai", pp. 60, 69; Du, "Wang tongchun shilue", p. 28. 5. Ibid.

52. Yao, Wuyuan tingzhigao, II, p. 7; Imahori Seiji, Chūgoku hōken shakai no kōzō: so no rekishi to kokumei zenya no genjitsu [The social structure of feudal China: its history and the immediate reality before the revolution] (Tokyo, 1978), pp. 776-779. 
to place in search of well-irrigated plots, which earned them the name paoqing or "green-shoot chasers". 53

These categories were further divided into several subgroups across the social spectrum. At the top were land merchants who contracted large tracts of land from the Mongols and owned either shares of trunk canals or branch canals or both. The next level were proprietor farmers who acquired modest plots but owned no canals themselves, and therefore needed to purchase water rights from the land merchants. There was a certain degree of mobility between the two because of the capriciousness of the Yellow River, which could ruin or enrich farmers in unpredictable ways. Likewise, the tenants were also divided into two subgroups according to the different methods of rental payment: fixed-lease tenants who organized farming relatively independently, and sharecroppers who depended on the landlords to supply most or all means of production. At the other end of the spectrum was a group of long- and short-term laborers who hired out their labor at irrigation sites or farm estates owned by land merchants for wages. These were supplied by the influx of landless farmers and refugees from south of the passes in the wake of natural disasters. The application of wage labor, coupled with the privatized land ownership and growing estate economy, greatly facilitated the development of commercial agriculture in Hetao.

\section{COMMERCIAL EXPANSION AND INTEGRATION}

The economic boom in Hetao paved the way for further commercialization, urbanization, and Hetao's integration into larger regional and global economic flows during the late nineteenth and early twentieth centuries. On the one hand, the rapidly expanding grain trade increasingly integrated Hetao with the market of north China, thanks to the water transportation provided by the Yellow River, which was navigable by wooden boats from Shizuizi in Ningxia to Qikou in Shanxi between April and November. ${ }^{54}$ On the other hand, the opening of treaty ports and construction of roads and railroad lines further integrated this borderland with the global market as a source of wool, pelts, and medicinal herbs.

As Han settlement expanded, commerce and handicraft industry flourished. Apart from their engagements in irrigation and land management,

53. Yao, Wuyuan tingzhigao, II, p. 7 .

54. Navigability of the Yellow River varied by season of the year and by section. It is not navigable from December through March due to freezing. The part between Lanzhou to Ningxiafu was passable only by rafts. The section between Dengkou and Hequ was navigable both ways, whereas the sections between Shizuizi and Dengkou and between Hequ and Qikou were good only for downstream traffic because of the narrow course and stony bottom. See Fan Rusen, "Minguo yilai de huanghe hangyun" [Navigation on the Yellow River since the Republican Period], Lishi dili, 24 (2010), pp. 28 5-300. 
the land merchants were predominantly merchants specializing in the longdistance trade of tea, cotton cloth, tobacco, and other Chinese products for the livestock and pastoral products of the Mongols; some were also engaged in handicraft industries such as food processing and felt making. Commerce and agriculture often sustained one another in these enterprises: while profits from commerce were invested in irrigation and land acquisition, proceeds from land were in turn converted into merchant capital.

Take Longxingchang, the largest trading firm in Hetao, for example. It was founded by a former Qing officer named Guo Xiangrong in I 880 and acquired by Wang Tongchun in I893. The firm sold grain, oil, pelts, medicinal herbs, and soda to Baotou and Hekou, in exchange for consumer goods from China proper. It also participated in the trade of lumber and coal that were procured from Mt Helanshan and the mines near Baotou. The firm was equipped with around 200 iron and wooden-wheeled carts, dozens of wooden boats, and over 100 camels, which traversed the trade routes between Mongolia and north China over land and water. It also operated a set of mills, oil presses, distilleries, and felt shops, as well as engaging in the credit sale of consumer goods. ${ }^{55}$ The commercial success of the firm not only supplied the capital needed in the irrigation endeavors of Wang Tongchun, but also gave rise to the market town that bore the same name as the firm. Located on the bank of the Yihe canal $35 \mathrm{~km}$ north of the Yellow River, the market town Longxingchang served as an important trade link between the regional market system and the hinterlands of western Inner Mongolia.

The thriving commerce of Hetao testified to the emergence of an interlinked regional economy that encompassed both sides of the Great Wall, bound together by extensive caravan and water transport routes. The completion of the navigable Yihe canal in 1893 facilitated the flow of goods within Hetao, and connected the area with other parts of Mongolia and north China via downstream market centers like Baotou and Hekou. Two cart roads linked these river ports to overland traffic, one extending from Baotou northward to Mongolia, and the other from Hekou eastward to Fengzhen and Datong in Shanxi. The rise of a grain base north of the Great Wall thus considerably reduced transport costs and enriched contractors and brokers in these market towns.

With new land brought under cultivation, cross-regional grain trade became phenomenal. Every year, between I 20,000 and I 80,000 tons of grain was transported from Hekou to the markets of north China, a large proportion of which came from Hetao. Further, a good proportion of the Hetao grain (up to 30,000 tons a year) was transported to Mongolia

55. Su Xixian, "Longxingchang shanghao xinshuai shimo" [Rise and fall of the trading firm Longxingchang], in the Seventh CPCC Wuyuan County Committee (ed.), Wuyuan wenshi, 6 (1998), pp. $36-38$. 
via Baotou. ${ }^{56}$ As the local gazetteer notes, "Upon harvest, the grain is immediately transported via the Yellow River and sold to the markets of Baotou, Hequ, and Qikou. No attempts are made to store it because of the easy profits." 57 The mountainous areas of northern Shanxi and Shaanxi, in particular, had long depended on grain imports from the north China plain. This dependence was exacerbated during the frequent natural calamities that plagued north China during the late nineteenth century. Thanks to its extensive irrigation systems, Hetao continued to produce grain in years when drought and famine caused grain prices to soar across north China and many parts of Inner Mongolia. During the famine of I89I-I892, the price of coarse grain (such as maize, millet, and sorghum) in Inner Mongolia quadrupled from 300 to I, 200 copper coins per dou (i.e. 60 taels per shi) and that of wheat rose from 700 to I, 800 coins per dou (i.e. 90 taels per shi).$^{58}$ The famine thus provided an opportunity for the land merchants to profit from the grain trade. In I892, Wang Tongchun sold 25,000 shi of grain to northern Shanxi and Shaanxi, and donated ro,000 shi of famine relief to Beijing. In I90I, he again sold $\mathrm{I} 2,000$ shi to Shanxi, 6,000 shi to Beijing, and 7,000 shi to Otog banner of Ordos. ${ }^{59}$

Apart from the grain trade, the trade of wool and pelts also flourished. The Treaty of Tianjin $(1858)$ opened more Chinese ports to foreign trade, while granting foreign merchants tax exemption on exports purchased inland except for a single charge of 2.5 per cent. ${ }^{60}$ The treaty paved the way for large-scale exports of wool and pelts from Mongolia to the wool textile and leather industries of Europe and America. Following the opening of Tianjin in I860, foreign firms from Germany, Great Britain, and the United States began to establish branch offices in Inner Mongolia that purchased rawhides, goatskins, and sheep and camel wools, and transported them to overseas markets via Tianjin. Specialized wool and pelt firms mushroomed in Baotou and Hohhot, which served as commission-based brokers (yaji) mediating between itinerary traders and foreign firms. ${ }^{61}$ According to Imperial Customs data, the export amount of wool and pelts increased

56. Zhang Rui, "Guzhen hekou" [Old market town Hekou], in Committee of Cultural and Historical Data, CPCC Inner Mongolia Committee (ed.), Neimenggu wenshi ziliao, 33 (1988), pp. 2 I 5-2 I9, 2 I 5; Duan Shengwu, "Kaifa Hetao de shangque” [Opinions on developing Hetao], Yugong banyuekan, 6:5 (1936).

57. Yao, Wuyuan tingzhigao, II, p. 2.

58. "Wuyuan diqu ziran zaihai shiliao" [Historical materials on natural disasters in Wuyuan], in Wuyuan shiliao buiyao, 7 (1984).

59. Su, "Wang Tongchun - Hetao shuili kaifa de jiechu rencai", pp. 67-68.

60. Wang Yi and Zhang Chengqi (eds), "Xianfeng tiaoyue" [Treaties of the Xianfeng era], in Shen Yunlong (ed.), Jindai zhongguo shiliao congkan xubian [Sequel edition of the collection of historical materials on modern China] (Taipei, I974), Treaty of Tianjin, Article XXVIII.

6r. Wu Shengrong, "Woguo xibei pimao jisan zhongzhen Baotou de pimao hangye" [Wool and pelt business in Baotou, distribution center of northwest China], in Committee of Cultural and 
forty-fold from 310,000 customs taels in 1876 to $13,370,000$ taels in I899, and despite a temporary setback at the time of the Boxer Rebellion in 1900, reached 26, 120,000 taels in 1905. Likewise, their ratio in the entire export of north China ports rose from 0.4 per cent in I 876 to II.5 per cent in I905, while the price for wool and pelt shot from less than 9 taels per picul in 1895 to over i7 taels for wool and 26 taels for pelt in $1905 .{ }^{62}$

Another important export from the Ordos region (Hetao included) was medicinal herbs. In particular, the trade in licorice root, a wild desert plant found in many parts of Inner Mongolia, became extremely profitable because of high demand on the world market. Its extracts were widely used in cough syrups, as well as the flavoring of chewing gum, tobaccos, nonalcoholic beverages, soy sauce, etc. The trade was largely monopolized by merchants from the Baode prefecture of Shanxi, who hired workers to dig the licorice roots in Hanggin and Dalad banners as well as other parts of the Ordos from April through September. The roots were then sold to the firms at low prices and transported to Baotou and Hekou by caravan or boat. Hekou was especially known for its enormous trade in licorice roots. In the late I 800 s, up to 5 million catties (3,000 tons), a total worth of 400,000 taels, were concentrated here every year and shipped to Hequ and Qikou and further to Tianjin and Qizhou in Zhili (present Anguo of Hebei province). ${ }^{63}$

The expanding long-distance trade gave rise to new urban centers that linked Hetao to a trading network spanning both sides of the Great Wall and reaching out to the world market through treaty ports like Tianjin. New market towns emerged in Hetao and on its immediate periphery, the most significant being Longxingchang, which served as a collecting and distributing center of grain and pastoral products, supplied by emerging local markets in Ulaan Obbo, Xiaoshetai, and Dashetai along the caravan routes to Urad banner as well as Mongolia. ${ }^{64}$ The second half of the nineteenth century also saw the rise of new regional market centers along the Yellow River. Located $200 \mathrm{~km}$ east of Hetao, Baotou became a major trading hub and tax port on the trade routes to Gansu, Xinjiang, and Mongolia, thanks to its easy accessibility to both land and water transport. Hekou, situated $150 \mathrm{~km}$ further downstream, remained the largest distributing center of licorice roots into the first quarter of the twentieth

Historical Data of CCPCC Inner Mongolia Committee (ed.), Neimenggu gongshang shiliao, 39 (1990), pp. 2 I 5-262.

62. Huang Yanpei and Pang Song, Zhongguo sishinian haiguan shangwu tongji tubiao, I876-I9Is [History of China's failure in commerce: statistical tables and graphs of forty years of customs commerce] (Shanghai, I917). I picul $($ dan $)=100$ catties $(j i n)=60-64 \mathrm{~kg}$.

63. See Zhang, "Guzhen hekou", p. 2 I 5 . The export of licorice roots reached its height in the I910s and I920s due to World War I, which totalled from 400-1,500 million piculs a year for 400,000-2,000,000 taels of silver; See He, Chasui mengmin jingji de jiepou, pp. 90-9I.

64. Su, "Wang Tongchun - Hetao shuili kaifa de jiechu rencai", p. 56. 
century. Its business waned only after the railway from Beijing to Hohhot was extended to Baotou in 1923 which provided a far more efficient means of transportation than carts and boats. ${ }^{65}$

The emergence of Baotou and Hekou indicated a trend of urbanization characterized by a high degree of commercialization as well as mutual dependence between economic cores and their peripheries that was mediated by the market rather than political or symbolic power. Unlike earlier frontier centers like Hohhot and Urga that were typically amalgams of ManchuMongolian politico-cultural control and Han merchant initiatives, these new market centers grew out of the Han commercial expansion relatively independently of official intervention. These were further linked to the frontiers of Mongolia, Qinghai, and Xinjiang, as well as to downstream river ports like Hequ and Qikou and to the treaty port of Tianjin. From these ports, the exports reached the markets of north China and the world, and this expanding trading network integrated the hinterlands of Mongolia into the larger regional and global economic systems.

\section{CONCLUSION}

In this article, I have examined the emergence of Hetao as a prosperous Chinese agricultural colony outside the Great Wall during the nineteenth century, which exemplified a new form of economically driven settlement that was distinguished from the earlier modes of strategically or ecologically triggered migration. The economic boom was made possible by a set of ecological, historical, and social conjunctures. First, it took place on a geographical and cultural periphery, with favorable irrigation conditions and water transport provided by the Yellow River, large amounts of arable land owned by the Mongols, and negligible interference by the state that allowed ample room for a vigorous local autonomy. Second, the ongoing Chinese commercial expansion and labor migration across the Great Wall into the grasslands paved the way for the irrigation boom in Hetao by supplying the capital and labor needed. Third, the process of commercialization was greatly accelerated during the late nineteenth century: while the social turmoil and natural calamities in north China supplied a large amount of cheap labor for commercial agriculture in Hetao, the expanding trading network further integrated the region into larger regional and global economic flows.

While these structural factors were indispensable in understanding the economic development and social change in Hetao, social actors played an equally significant role. At the center of the agricultural boom was the group of land merchants who combined capital with expertise in

65. Wu, "Woguo xibei pimao jisan zhongzhen Baotou de pimao hangye", p. 215; Zhang, "Guzhen hekou", p. 2 I6. 
developing irrigation works and organizing commercial agriculture. By obtaining hitherto uncultivated land from the Mongols and investing in irrigation systems, the land merchants were able to increase significantly the value of water and land, thereby turning these resources into profitgenerating assets and commodities on the market. They also successfully mobilized capital, expertise, land, and labor through an innovative shareholding system, characterized by a lively trade in shares, multiple levels of ownership, and cross-investment. The high returns in turn incentivized them to expand reproduction by establishing large-scale managerial farms using hired labor, and participating in long-distance trade and handicrafts industries, thereby integrating the area into the larger regional and global economic systems. All these gave rise to a capital-intensive, market-oriented mode of production centred on massive capital accumulation, commercial agriculture, and wage labor, which can be best described as capitalist.

On the other hand, there were admittedly limits as to what kind of development these arrangements were capable of over the long run without the input of modern technology or legal frameworks. Much of the investment made by the land merchants was relatively short-term working capital money spent to pay workers involved in digging and dredging processes that needed to be partially repeated frequently - rather than long-term investment in physical capital with a low depreciation rate or modern technology that could be used to improve efficiency. It therefore remains unclear as to what extent this development was sustainable beyond the initial stage of frontier thrust, had it not been subject to state intervention.

Further, the lack of a modern legal system made this development vulnerable to internal disorder and external coercion, partly because the property rights of the entrepreneurs, though acknowledged in customary practices, were not protected by governmental laws. The economy of Hetao suffered under the double pressures of the extortionate military and banditry during the I870s. Later, starting from 1902, the state-making efforts of the Qing and Republican governments, in particular the expropriation of private canals, resulted in the eclipse of land merchants as major actors on the local scene and eventually the decline of the Hetao economy. They continued to play a role as land brokers and absentee landlords into the Republican period, yet the degree of capital investment on irrigation was hardly comparable with its prime in the nineteenth century. Many canals silted up due to poor maintenance, and by 1919, the irrigable area of Hetao shrank to a mere 23,000 hectares, about one-third of the figure of $1907 .{ }^{66}$

Nevertheless, the existence of such positive, domestically financed and organized developments, however short-lived, counters the conventional 
view that the Chinese kept reproducing the same involutionary structure and were incapable of initiating change on their own. The case of Hetao thus provides an example of how change was made possible from the periphery where certain geographical, historical, and socio-economic contingencies met, and how a group of local actors were able to induce fundamental change that not only had enduring impact upon the frontier society, but also facilitated China's integration into the emerging global economy of the late nineteenth century.

\author{
TRANSLATED SUMMARIES \\ FRENCH - GERMAN - SPANISH
}

Yi Wang. Irrigation, commercialisation et changement social en mongolie intérieure au dix-nenvième siècle.

Cet article examine l'essor de l'économie de l'irrigation à Hetao au bord du Fleuve Jaune pendant le dix-neuvième siècle et la prend comme étude de cas pour illustrer le rôle important, bien que méconnu, de la périphérie dans l'évolution de l'économie chinoise, ce qui réfute l'idée conventionnelle d'un mode de développement chinois qui reproduisit l'exploitation agricole à petite échelle. Je me concentre sur un groupe d'entrepreneurs de Han connus en tant que marchands de sols (dishang); ils allièrent capitaux et expertise dans le développement de l'irrigation et introduisirent un nouvel ordre associant un régime de la propriété et des arrangements sociotechniques qui changèrent fondamentalement la société de la frontière. Reliant les transformations dans la société locale aux processus régionaux et mondiaux, cette étude démontre la centralité de la périphérie. Elle fut non seulement un zone de possibilité et d'expérimentation mais surtout une "zone de contact" qui facilita l'intégration de la Chine dans un nouveau système de marché mondial.

\title{
Traduction: Christine Krätke-Plard
}

Yi Wang. Bewässerung, Kommerzialisierung und sozialer Wandel in der inneren Mongolei des 19. Jabrbunderts.

Dieser Beitrag untersucht den Aufstieg der Bewässerungswirtschaft in Hetao am Gelben Fluss während des 19. Jahrhunderts. Die Bewässerungswirtschaft dient als Fallstudie, um zu veranschaulichen, wie die Peripherie in der Entwicklung der chinesischen Wirtschaft eine bedeutende und dennoch übersehene Rolle gespielt hat: eine Rolle, die der herkömmlichen Sicht auf den chinesischen Entwicklungspfad als Vervielfältigung kleinbäuerlicher Wirtschaft entgegensteht. Der Beitrag fokussiert auf eine Gruppe von Han-Unternehmern, die als Landkaufleute (dishang) bekannt waren; sie verfügten über Kapital und waren zusätzlich Experten für die Entwicklung von Bewässerungssystemen. Diese Unternehmer führten eine neue Kombination von Eigentumsformen und sozialtechnischen Regelungen ein, die die Gesellschaft im Grenzgebiet grundlegend veränderte. Indem er lokale 
gesellschaftliche Veränderungen zu regionalen und globalen Prozessen in Beziehung setzt, zeigt der Beitrag die Zentralität der Peripherie auf, nicht nur als Zone der Möglichkeiten und des Experiments, sondern, was noch bedeutender ist, als "Kontaktzone", die die Eingliederung Chinas in ein neues globalen Marktsystem erleichterte.

Übersetzung: Max Henninger

Yi Wang. Irrigación, comercialización y cambio social en el interior de Mongolia en el siglo XIX.

En este artículo se examina el proceso de expansión de la economía basada en la irrigación de la región de Hetao en las orillas del río Amarillo a lo largo del siglo XIX y se utiliza como un estudio de caso para ilustrar cómo la periferia jugo un papel importante, pero ignorado hasta el momento, en el desarrollo de la economía china. Esta perspectiva viene a matizar la perspectiva convencional de la existencia de una vía china de desarrollo que reproducía el modelo de la pequeña propiedad agraria. En el texto nos centramos en el análisis de un grupo de empresarios Han, conocidos como mercaderes de tierras (dishang), que combinaron tanto capital como experiencia en el desarrollo de la irrigación e introdujeron un nuevo modelo de régimen de propiedad e innovaciones socio-técnicas que modificaron de forma sustancial la estructura de las fronteras sociales. Así, estableciendo vínculos entre los cambios habidos en la sociedad local con aquellos observados en la regional y en los procesos globales, este trabajo demuestra la centralidad de la periferia, no sólo como un área de posibilidades y de experimentación sino, algo mucho más importante, como una "zona de contacto" que facilitó la integración de China en un nuevo sistema de mercado global.

Traducion: Vicent Sanz Rozalén 